\title{
Benoît Vermander, Les Mandariniers de la rivière Huai: Le réveil religieux de la Chine
}

Paris, Desclée de Brouwer, 2002, 257 pp.

Jean-Paul Wiest

\section{OpenEdition}

\section{Journals}

Édition électronique

URL : http://journals.openedition.org/chinaperspectives/656

DOI : $10.4000 /$ chinaperspectives. 656

ISSN : 1996-4617

\section{Éditeur}

Centre d'étude français sur la Chine contemporaine

Édition imprimée

Date de publication : 1 octobre 2003

ISSN : 2070-3449

\section{Référence électronique}

Jean-Paul Wiest, «Benoît Vermander, Les Mandariniers de la rivière Huai: Le réveil religieux de la

Chine », China Perspectives [En ligne], 49 | september-october 2003, mis en ligne le 17 janvier 2007, consulté le 21 septembre 2020. URL : http://journals.openedition.org/chinaperspectives/656 ; DOI https://doi.org/10.4000/chinaperspectives.656

Ce document a été généré automatiquement le 21 septembre 2020.

(c) All rights reserved 


\title{
Benoît Vermander, Les Mandariniers de la rivière Huai: Le réveil religieux de la Chine
}

Paris, Desclée de Brouwer, 2002, 257 pp.

\author{
Jean-Paul Wiest
}

1 Benoît Vermander, director of the Ricci Institute in Taipei, draws on historical, sociological, artistic and theological data and analysis to reveal signs that are the harbingers of a religious awakening intrinsically linked to the present social and cultural transformation of China. For him the recent religious fever (zongjiao re)revival of Taoism and Buddhism, persistence of traditional rituals, effervescence of new religious groups, and renewed interest in Christianity-will be no more than a passing, or at most recurring, phenomenon unless it expands beyond the realm of the "private". The "religious transformation" that he forecasts should instead bring about a "transcendental encounter" between the profane and the spiritual and it should occur when religions begins to address the social, moral, ecological and educational problems that confront China's present and future development. In this encounter, Vermander pays special attention to the transformation of Chinese Christianity.

2 This book is a real tour de force in the sense that the author weaves in very naturally his own spiritual awakening and quest for the Absolute with the religious awakening and quest for the Absolute at play in the whole of Chinese society. Vermander's goal is not so much to make a rational and "sensible" presentation but rather to take the reader along on a journey through the Chinese esthetic and spiritual cultural landscape. According to an old local Chinese saying, tangerine trees on the south bank of the Huai river produce sweet fruits while the same trees on the north side yield only sour ones. From the viewpoint of the future of Christianity in China, says Vermander, this anecdote raises the three basic questions that he intends to address: 1) Will the Chinese soil enable the transplanted tree to bear sweet fruits? 2) Will a Chinese graft ensure sweet fruits? 3) Can the tree survive without a symbiotic relation to the other 
natural religious species of China? For an answer, the author invites the reader to hear the promise of the future harvest in the murmur of the wind through the branches.

3 Vermander makes ample use of articles he published previously, but has reworked and updated them into a rather coherent nine-chapter volume. In the first chapter, the author unveils himself, so to speak, by revealing what caused his own awakening along his heretofore unfinished journey: the encounter with Asian culture, art, values and religions; the friendship of specific individuals; and the sharing of daily life with the Nuosu and Yi minority peoples.

Christianity in China is the religion of a small minority. Chapter 2 takes a look at the budding prophetic role played by some Christian communities and individuals. It also analyses the historical tension between Rome and Peking and the controversy caused by the canonisation of October 1 st 2000.

The next chapter reflects on the impact of globalisation on the religious awakening in China. Vermander suggests that this process as we know it today is in fact a phenomenon as old as humankind. He argues that the purpose of the dialogue between China and the Occident is to give a soul to globalisation by inventing together points of reference and cultural models that answer the challenges of this globalisation. By the same token, no Chinese religion can give meaning to what Chinese people are experiencing today if it stays self-centred and ignores the transformation brought along by globalisation. There is no hope of a long-lasting religious awakening without embracing the intercultural encounter brought about by globalisation.

6 The following two chapters take the point made in the previous chapter further by focusing on contemporary Catholicism within the Chinese context. Chapter 4 looks at the difficulties and opportunities faced by Chinese theologians in giving rise to a truly Chinese Christian theology. In Chapter 5, Vermander presents "faces of Jesus" that he believes China will welcome. Jesus the "Humble Stranger" does not represent the imposition of another culture and is more likely to be heeded like that of the tiny human figure who within a Chinese painting is in fact the eye that gives the canvas its true meaning and dimension. Jesus the "Teacher", Jesus the "Unfathomable", Jesus the "Living" who dispenses his Spirit $(Q i)$ and opens the Way (Dao) are all figures in symbiotic relations with the Chinese own spiritual tradition. In conclusion Vermander points out that the task for the theologians has just begun and suggests several avenues that urgently warrant the attention of Catholic researchers.

7 Chapters 6 to 8 provide the reader with three different contexts of the reality of Chinese religions in contemporary China. In Chapter 6, Vermander describes Taiwan as a rich field of religious diversity. Its economic and social growth, in contrast to many other developed countries, has gone hand in hand with an amazing religious vitality. Popular religions and traditional Buddhist forms as well as new ones are all flourishing. Christianity is lagging behind and needs to "reinvent" itself if it wants to be pertinent to a Taiwan culture in perpetual transformation. Vermander thinks it is not too farfetched to think that what is happening in Taiwan in the religious sphere prefigures what China will also experience in a not too distant future.

8 Chapter 7 provides a thorough analysis of Falungong. The notoriety this recent phenomenon has achieved makes it a perfect example of the situation and impact of "new religions" in China. With Chapter 8, Vermander turns to the religious world of the Nuosu people of Sichuan province. He finds that the religious intuitions and rituals that shape the lives of these people, far from being obsolete or out of touch with modern 
society, are in fact very relevant. They affirm that justice and solidarity remain stronger than solitude, violence, sickness and death.

With Chapter 9 Vermander leads the reader to an understanding of art as a religious phenomenon by which the "birth" of an art piece in the hands of the artist is the expression of the "birth" of God in the artist himself. Put in another way, "spiritual art" is one of the conduits through which the divine reveals something of its mystery and through which humans enter that mystery.

10 Vermander concludes his book by affirming that in China Christianity has a chance of becoming indigenous. It is like a young tree among the majestic giants of other Asian religions. Its growth to full maturity cannot happen in autarky, but only if it sinks its roots deep into that same rich Chinese spiritual humus that nourishes the others. Only this existential encounter will change how Christianity is perceived and received in Asia.

11 The criticism that can be made is that the book lacks a certain unity. Despite Vermander's efforts to weave all the chapters into a whole, some parts bear too much the marks of their previous existence as pieces written for a different purpose. Some readers may also object to or be taken aback by the author's mixing of literary genres and academic disciplines. But this is what Vermander intended to do by challenging us to let go of our too compartmentalised ways of thinking about and looking at the world, ourselves, and the divine. As such the book is difficult to classify, but this does not diminish its relevance and appeal. Anyone with the slightest interest in the place and role of religions in Asia will find the reading intellectually and spiritually stimulating. 